\title{
The importance of forestry and forest engineering: Past - present - future ${ }^{1}$
}

\author{
by Gilbert G. Paillé2
}

\begin{abstract}
Until 1900, Canada had no foresters involved in logging, practising forestry or doing research. Forest engineering as a discipline held no importance whatsoever. The forest was simply exploited for its timbers and most of the forest products were sold abroad. During the next 50 years, four Canadian universities opened forestry schools, some research activities were organized by the federal government, provincial governments, and industry. However, the importance of forest engineering did not grow much. Since 1950, however, the situation was turned around completely, as was the industry. While forest operations were completely mechanised everywhere in Canada with machines or concepts often developed in the USA or in Scandinavia, more forestry schools were opened, the federal government opened forest research laboratories, provincial governments acquired more expertise in this field, and forestry equipment manufacturers did considerable development work. A national forest engineering research institute was even created. In the future, the forest community will have to team up to raise the profile of forest engineering.
\end{abstract}

Key words: co-operation, forest engineering, forestry, forestry education, forestry research, sustainable management

Jusqu'en 1900, le Canada ne comptait aucun forestier au niveau de l'exploitation forestière, de la pratique de la foresterie ou en recherche forestière. Le génie forestier en tant que discipline n'avait aucune importance. Les forêts étaient simplement exploitées pour la matière ligneuse et la majeure partie des produits forestiers étaient vendus à l'étranger. Au cours des 50 années suivantes, quatre universités canadiennes ont ouvert des écoles de foresterie, des activités de recherche ont été organisées par le gouvernement federal, les gouvernements provinciaux, et l'industrie. Toutefois, le génie forestier na pas beaucoup grandi en importance. Depuis 1950, cependant, la situation s'est complètement modifiée, ainsi que l'industrie. En effet, les opérations forestières se sont mécanisées en totalité partout au Canada avec des machines ou selon des concepts souvent développés au É.-U. ou en Scandinavie; plusieurs universités ont été fondées; le gouvernement fédéral a ouvert des laboratoires de recherche forestière; les gouvernements provinciaux ont acquis plus d'expertise dans le domaine et les manufacturiers d'équipement forestier ont effectué beaucoup de travaux de développement. Un institut national de recherche en génie forestier a même été mis en place. Dorénavant, la communauté forestière devra se rallier pour relever le profil du génie forestier.

Mots-clés: coopération, génie forestier, foresterie, formation en foresterie, recherche forestière, aménagement durable

\section{Introduction}

I will attempt to briefly describe the evolution of forest engineering from the time the first Europeans touched ground in North America until now. Then, I will compare Canadian and Swedish foresters by describing the magnitude of the forest activities that they are managing. Finally, I will describe some of the major challenges that forest engineers should prepare to face in the future.

First, however, I want to establish my credentials by describing briefly my previous visits to Sweden with several Canadian foresters, forest engineers and forest industrialists of various affiliations.

The first visit took place in 1975 when I came with a small group of people sponsored by a Quebec forest consultant and hosted by Skogsarbeten. In those days, Canada was viewed as the Mecca of logging and Sweden the Mecca of silviculture. We Canadians were impressed then:

- by the training of brush saw operators and the slick organisation for precommercial thinning operations in Växjö;

- by the large trial on total utilisation of forest biomass including stumps and roots, with machines and mills developed for that purpose; and

- by the availability of cross-country ski trails, equipped with street lights to favour night activities.

${ }^{1}$ Keynote address to the 2nd Forest Engineering Conference in Växjö, Sweden, May 12, 2003.

${ }^{2}$ Forest Engineer, President and CEO of the Forest Engineering Research Institute of Canada (FERIC), Montreal, Quebec. E-mail: Gilbert-p@mtl.feric.ca.
My second visit took place in 1980 when I came with a large group of people representing several Canadian forest companies. We were sponsored by the Canadian Pulp and Paper Association (CPPA) and again hosted by Skogsarbeten. We were most impressed then by silvicultural activities and other aspects of the forestry business, such as:

- the global reforestation effort (prototype multiple-head

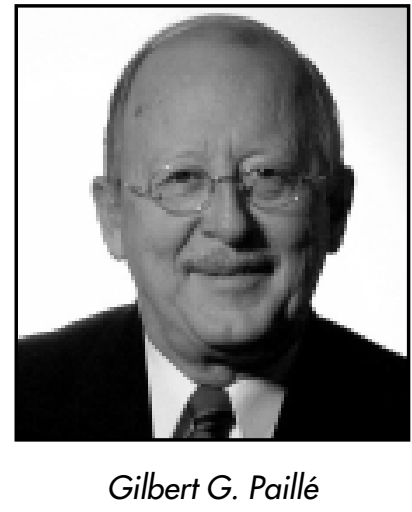
planting machine, large scale lodgepole pine plantations (450 000 ha) with seedlings grown from seeds harvested on selected plus trees in Canada, the high proportion of seeds already coming from seed orchards (70\% for pine), one large forest company planting 50 million trees a year, scarification conducted on morainic soils with disk trenchers and other mechanical and hydraulic attachments);

- the large amount of money invested in forestry research in Sweden compared to Canada;

- the new moose fertilising machine, and the butcher's shop (annual harvest of 130000 animals in 1980) located on campus at the University!

- the competitiveness of some Swedish tennis players trying to imitate Björn Borg (whom we defeated in a friendly game at Garpenberg!). 
The third visit took place in 1993 when I moved to Stockholm with my family and spent more than a year representing the Quebec provincial government there, trying to favour investments in Canada and technology transfers both ways. I visited Scandinavia during that period and I was mostly impressed:

- by the high visibility (dense road network) of silvicultural activities and the constant preoccupation for cleanliness and for all the aesthetic aspects of forest works;

- by the great simplicity of the Swedish Forest Act of 1994; and

- by the huge size of the trade surplus generated by forest products in Sweden when compared to Canada, two countries competing head on for a bigger share of the market in the European Union. I made a film on that topic that was shown when I returned to Canada.

The fourth visit took place in 2001. It was sponsored by the Forest engineering Research Institute of Forestry (FERIC) and hosted by SkogForsk. We brought a group of sixteen people representing member forest companies, government and woodlot owners. We visited ELMIA WOOD and we prepared a nice report. We were less impressed by silviculture this time and more:

- by the emphasis placed on wood freshness (maximum three-week delay between the felling of trees in the forest and their delivery to mills);

- by the most modern sawmill in the world at Mönsteras, with no machine to be seen, no dust, no noise and almost nobody on the floor;

- by dual-function forest machinery (like the Harwarder);

- by high-tech decision-aid electronic systems on a variety of equipment, allowing transfer of data between machine, office and customer; by systems to recover biomass for energy; and by systems to ensure operator safety and comfort. When I was here on those previous visits, I was also personally impressed on several occasions by the consensus that existed on a large number of issues in forestry in Sweden. Four years ago, I finally discovered how it came to be when I was invited to participate in a Royal Technology Mission of His Majesty King Carl XVI Gustaf to Canada. On that occasion, the King travelled with several Presidents and CEOs of large forest companies and other corporate organisations, all members of the Royal Academy of Sciences of Sweden. After visiting the forest and several mills in Quebec, the members of the Academy had ample time while travelling to reflect and to make up their minds on the issues at hand, and to develop a consensus on the degree of evolution reached in Canada when compared to Sweden. I was told that the Academy travelled at least once a year to a different destination. I thought that this was a fantastic way for the King to exercise his leadership, and for him to help establish a consensus amongst the leaders of his country on many aspects of the economy. Upon their return, I assumed that the consensus was flowing down from them.

Surely, we Canadian forest engineers who do not accompany our Queen or even our Prime Minister to the bush very often, have fewer opportunities than Swedish foresters to put our heads together, and to develop necessary consensus on important issues facing the forest sector under the leadership of our elite.

This being said, I will now turn your attention to the historical importance of forest engineering in Canada.

\section{Past Importance of Forest Engineering From 1600 to 1900}

Early in the 17th century, forest engineers would have been needed in eastern Canada to conduct forest surveys, to lay out roads through the bush, to build logging camps, to organise the harvest of large pine timbers, and to manage their water transportation to sawmills and sea ports. Unfortunately, there were none in the country, and none came from abroad. And the same situation prevailed during the 18th and the 19th centuries.

Therefore, during 300 years, those who organised the forest operations in Canada were French or British entrepreneurs supported by the Kings in their countries. Those who carried out the forest work were mostly local contractors aided by farmers, who learnt how to swing the axe and the cross-cut saw when they deforested their own woodlots; by fishermen, who did not fish during winters; and by some rough necks who simply loved the hard bush work to earn a living.

Late in the 19th century, some mechanical equipment started to be used in Canadian operations, especially on the West Coast.

In summary, before 1900, there was no scientific forestry practised in Canada. Forest activities were conducted by entrepreneurs, and the ground work was executed by local manpower with imported equipment. Forest engineering as a science had no importance whatsoever. This period was identified as the Forest Liquidation Era.

\section{From 1900 to 1950}

In 1903, the first forester came to Canada from Germany, and by 1950, forestry education was offered at four universities_-Toronto (1907), Fredericton (1908), Quebec (1910) and Vancouver (1921).

Forestry research was also launched during that period. In 1917, the Petawawa Forest Experiment Station was opened by the government of Canada. In 1921, the BC Forest Service organised a provincial Forest Research Branch, and Ontario created a Directorate of Forest Research in 1929. In 1927 the forest industry became involved in the betterment of logging methods when Alexander Koroleff, a Siberian logging engineer, was made responsible for managing the Woodlands Section of the Canadian Pulp and Paper Association. He became a prominent figure around the world in research and development of logging equipment, mostly after he became a Director of Woodlands Research at the Canadian Pulp and Paper Research Centre in 1942.

The importance of forest engineering grew very quickly in western Canada during that period. These were the pioneering days of mechanisation of forest operations on the West Coast. Securing access to old-growth forests was one major challenge and moving the massive timber pieces to market by land and sea was another.

In eastern Canada, most of the efforts in the forest sector were devoted to the establishment of the pulp and paper industry; approximately 100 pulp and paper mills were built during that period alone. On the one hand, supplying pulp and paper mills with short bolts of small trees was seen as a simpler exercise than the previous challenge to produce ship masts, square timber and big sawlogs for hundreds of years. It could be done by hands with horses. Not much new forest operations knowledge was needed. Moreover, mature natural forests were seen as being so extensive and so resilient that relatively little attention was devoted to growing them or to renewing them artificially. 
Therefore, "silvicultural" engineering was not needed either. This was identified as the Conservation Era.

In summary, during the first half of the 20th century, a few forestry schools were opened and the first Canadian foresters graduated. Forest sector research was organised and forest operations were mechanised on the West Coast.

\section{From 1950 to 2000}

Forestry education and forestry research became a major preoccupation at several universities when the older schools of forestry started offering graduate studies and four new forestry schools offered programs in forest sciences: Edmonton (1970), Thunder Bay (1971), Moncton (1985), and Prince George (1993) (Table 1).

Even if university forestry education was being provided at eight different universities in the year 2000, forest engineering was still not a dominant preoccupation. Only three out of eight schools were offering programs in this field of activity: a bachelor of science in forest engineering was offered only at the university of New Brunswick in Fredericton (since 1964); a bachelor of science in forestry with a major in forest operations was offered at UBC in Vancouver, and a bachelor of applied sciences in forest operations could be obtained at Laval in Quebec. In BC, a yet to be recognised "diploma program in advanced forest engineering" also became available in 1997; it was targeted at practising foresters.

In 2000, the trend in forestry education was definitely away from the engineering aspect of forestry and more towards the biological and environmental aspects. In fact, at many universities, forestry was presented as an environmental science and the names of the faculties of forestry became, for example: Forestry and the Forest Environment; Forestry and Environmental Management; Natural Resources and Environmental Studies. The recruitment of students in forestry became increasingly difficult everywhere in the country. For example, enrolment in undergraduate forestry programs declined 27\% between 1998 and 2002, according to the Forest Products Association of Canada (FPAC).

Forestry research became a major preoccupation of the federal government only after 1950. Six regional laboratories were then opened by the Canadian Forest Service across the country. Their expertise was mostly focussed on the biological aspects of forestry.

Provincial governments also got more involved in research on the biological side of forestry. After BC and Ontario, Quebec created a Forest Research Directorate in 1967, and Alberta entered the race in 1980.

Woodlands research was supported by the independent Pulp and Paper Research Institute of Canada, and the Forest Management Institute of the Canadian Forest Service, in collaboration with some forest companies until FERIC was created in 1975. This is when pre-competitive forest engineering research was divorced from pulp and paper research. Both the federal government and the forest industry agreed to support this new and unique venture in North America. Soon, provincial governments also showed interest, and so did about 100 large and small forest companies.

During this period, considerable research was also conducted by the equipment-manufacturing sector in Canada. In 1980, for example, there were approximately 50 manufacturers involved, $20 \%$ of which were in the harvesting sector. Since
Table 1. Forestry, forest operations and forest engineering education in Canada

1. The University of British Columbia at Vancouver, British Columbia Faculty of Forestry -4 programs

1. Forest Operations (BSc Forestry)

2. Forest Resources Management

3. Forest Sciences

4. Natural Resource Conservation

2. The University of Northern British Columbia at Prince George, British Columbia

Faculty of Natural Resources and Environmental studies - 1 program 1. Forestry (BSc Natural Resource Management)

3. The University of Alberta at Edmonton, Alberta

Faculty of Agriculture, Forestry and Home Economics - 5 programs

1. Forestry (BSc Forestry)

2. Forest Business Management (BSc Forest Business Management)

3. Conservation Biology

4. Environmental Economics and Policy

5. Human Dimensions of Environmental Management

4. Lakehead University at Thunder Bay, Ontario

Faculty of Forestry and the Forest Environment -2 programs

1. Forestry (BSc Forestry)

2. Environmental Studies

5. Laval University at Sainte-Foy, Québec

Faculty of Forestry and Geodesy -3 programs

1. Forest Operations (BScA Forest Operations)

2. Forest Resource Management

3. Forest Environment Management

6. The University of New Brunswick at Fredericton

Faculty of Forestry and Environmental Management - 2 programs

1. Forestry (BSc Forestry)

2. Forest Engineering (BSc Forest Engineering)

7. The University of Moncton at Edmundston, New Brunswick

Faculty of Higher Education and Research - 1 program

1. Forest Sciences (BSc Forest Sciences)

8. The University of Toronto, Ontario

Faculty of Forestry - 1 program

1. Forest Conservation (M Forest Conservation)

9. Forest Management Institute of British Columbia

Continuing Education - 3 programs

1. Diploma program in Advanced Forest Engineering

2. Silviculture Diploma

3. Silviculture Technical Program

then, the total number of manufacturers doing research increased, and their expenditures were estimated at approximately $10 \%$ of the total for the forest sector. However, their work being proprietary was difficult to identify or to quantify precisely. Because of the limited market for forestry machines in Canada, manufacturers and distributors imported a large proportion of the equipment needed to conduct Canadian forest operations from abroad.

At the end of the period, the total value of the forest sector research effort in Canada was $\$ 345$ million (1999) of which $45 \%$ came from the private sector, $30 \%$ from the federal government, and $25 \%$ from the provinces. The support from industry was directed mostly at forest product research, and the support from governments at forestry research. Forest engineering research was getting less than $3 \%$ of the total investment in research by governments and by industry; it went almost all to FERIC. 
When compared with the value of shipments of all forest products ( $\$ 73$ billion in 1999), this investment in forestry research represented less than one half of one percent, and Canada was not viewed as a leader amongst other developed nations.

During the second half of the 20th century, all logging operations became completely mechanised both in eastern and western Canada. Technical innovation and mechanisation of forest operations resulted in a sevenfold increase in man-day productivity. In the east, four-wheeled skidders (1950) came on the market, hydraulic log loading grapples (1952), bulldozers (1955), flail delimbers (1956), feller bunchers (1957), logging trucks (1960), shortwood harvesters (1970), road side processors and feller forwarders (1976). After 1975, other machines were also put to work: stroke delimbers (1980), clambunk skidders, mechanical roadside slashers, and harvesters, to mention only a few.

In the west, several pieces of equipment had already been developed before 1950. Suffice to mention the logging trucks (1915), high-lead cables (1920), gas-powered chain saws, yarders (1930), and bulldozers (1938). After 1950, mechanisation was completed on the West Coast and launched in the Interior. Feller bunchers and grapple skidders hit the market in 1968, wood barging in 1975, and helicopter logging in the 1980s.

However, most of the pieces of equipment were developed in the USA. Examples are the bush combine (1959), the Prentice loader (1960), the Beloit harvester (1964), the Drott feller buncher (1968), and the Timbco feller buncher (1980s). Some logging and silvicultural equipment was also imported from Sweden. Let us mention, for example, some debarking machines (1955), processors (1966), forwarders (1969), delimbers (1970), scarifiers (1970), planting machines (1983), and brushing heads (1985). Canadian manufacturers for their part developed or improved some equipment like power saws, and portable steel spars, and some machinery like four-wheeled skidders, feller bunchers, the LRA logging system, and the knuckleboom delimber.

In summary, during the sustainable forest management era (1950 to 2000), the population of Canada grew from 15 million inhabitants to 31 million (Table 2). At the same time, the harvest of wood increased rapidly from 80 million cubic meters a year to 197 million (Table 3), and all forest operations were completely mechanised. However, the importance of forest engineering did not grow at the same rate as the operations. Education shifted slowly towards the biological and environmental aspects of forestry. Research in forestry received a relatively low level of attention, and research in forest engineering got only $3 \%$ of the total amount of money invested in the sector. The mechanisation of forest operations was realised mostly with equipment developed outside of Canada; research in forestry equipment received only about $2 \%$ of the global financial allocation in the forest sector.

\section{Present Importance of Forest Engineering}

Now that we have reviewed the evolution of forest engineering in Canada, let us compare its present importance in Canada and in Sweden.

\section{Magnitude of the Forests}

First, we can compare the forests (Table 4). Canada is 22 times larger than Sweden but its productive forest land is only 10 times larger. Canada's forests are growing mainly in the public

\begin{tabular}{|c|c|c|}
\hline & Canada & Sweden \\
\hline Population (million) & $31(2002)$ & $9(2002)$ \\
\hline $\begin{array}{l}\text { Communities heavily depending on the forest } \\
\text { (number) }\end{array}$ & 300 & NA \\
\hline Establishments (number) & (1999) & (1997) \\
\hline Harvesting & 9541 & NA \\
\hline Wood work & 2144 & \\
\hline Paper work & 663 & 96 \\
\hline Board & & 13 \\
\hline Employment (thousand) & (2001) & (1997) \\
\hline Direct & 246 & 92 \\
\hline Logging & 55 & NA \\
\hline Forest Service & 24 & NA \\
\hline Indirect & 738 & 85 \\
\hline Value of wood delivered at the mill (billion \$) & 13.5 & 4.9 \\
\hline Volume produced & (1997) & (1997) \\
\hline Paper (million $\mathrm{t}$ ) & 20 & 10 \\
\hline Lumber (million $\mathrm{m}^{3}$ ) & 63 & 15 \\
\hline Pulp (million $\mathrm{t}$ ) & 25 & 11 \\
\hline Value of shipments (billion \$) & 73 (1999) & NA \\
\hline Volume exported & (2001) & (1997) \\
\hline Paper and cardboard (million tm) & 20 & 8 \\
\hline Lumber (billion fbm) & 28 & NA \\
\hline Pulp (million tm) & 11 & 2 \\
\hline Panel (billion sqft $3 / 8$ ) & 16 & NA \\
\hline Value of exports (billion \$) & $44(2001)$ & 17 (1997) \\
\hline Paper (\%) & 41 & NA \\
\hline Lumber (\%) & 25 & NA \\
\hline Pulp (\%) & 16 & NA \\
\hline Value of taxes paid to governments (billion \$) & $8(2001)$ & NA \\
\hline Trade surplus (billion $\$$ ) & $34(2001)$ & NA \\
\hline Contribution to GNP (billion \$) & 28 & NA \\
\hline Gas price $(\$ / L)$ & $0.75(2003)$ & 2.70 \\
\hline
\end{tabular}

Table 3. Harvesting and silvicultural activities

\begin{tabular}{|c|c|c|c|}
\hline \multirow[b]{2}{*}{ Activities } & \multicolumn{2}{|c|}{ Canada } & \multirow[t]{2}{*}{ Sweden } \\
\hline & Year 2000 & Year 1975 & \\
\hline Forest roads (thousand $\mathrm{km}$ ) & NA & & 310 \\
\hline \multicolumn{4}{|c|}{ Volume of wood harvested (million $\mathrm{m}^{3}$ ) } \\
\hline From Crown land & 157 & & NA \\
\hline From private land & 40 & & NA \\
\hline Total volume (2001) & 197 & & 70 \\
\hline \multicolumn{4}{|l|}{ Annual forest losses (million ha) } \\
\hline Wild fires & 2 & & NA \\
\hline Insect epidemics & 6 & & NA \\
\hline \multicolumn{4}{|l|}{ Silviculture (thousand ha) } \\
\hline Final felling & 913 & 680 & 300 \\
\hline Thinning and selection cutting & 132 & 0 & 270 \\
\hline Site preparation and scarification & 321 & 160 & 120 \\
\hline Planting & 400 & 127 & 200 \\
\hline Sowing & 26 & & NA \\
\hline Natural regeneration & 534 & & NA \\
\hline Fertilising \& draining & 22 & & 25 \\
\hline Cleaning & 442 & 37 & 180 \\
\hline \multicolumn{4}{|l|}{ Certified forests (million ha) } \\
\hline $\begin{array}{l}\text { Certified area managed on a } \\
\text { sustainable basis (2002) }\end{array}$ & 115 & & NA \\
\hline
\end{tabular}

domain (90\%) while in Sweden, it is approximately just the opposite: $87 \%$ are privately owned.

The annual increment of the Swedish forest at $4.2 \mathrm{~m}^{3} / \mathrm{ha}$ is four times the growth observed in Canada, and the average yield of productive forests at $130 \mathrm{~m}^{3} / \mathrm{ha}$ is $20 \%$ larger. 


\begin{tabular}{lcc}
\hline Table 4. Forest statistics & & \\
\hline \multicolumn{1}{l}{ Canada } & Sweden \\
\hline Land Tenure & & \\
Total land area (thousand ha) & 921 & 41 \\
Forest land (thousand ha) & 417 & NA \\
Productive forest land (thousand ha) & 237 & 23 \\
Public tenure & 214 & 3 \\
Private tenure & 23 & 20 \\
Family-owned (\%) & 78 & 60 \\
Company-owned (\%) & 22 & 40 \\
Growing Stock & & \\
Volume (million m3) & 25.7 & 3 \\
Yield (m3/ha) & 108 & 130 \\
Conifers (\%) & 76 & 89 \\
$\quad$ Hardwoods (\%) & 24 & 11 \\
Allowable Annual Cut & & \\
Total (thousand m3)(1999) & 240 & 97 \\
Annual Increment & & \\
Total (m3/ha) & 1.0 & 4.2 \\
Commercial Tree Species & $125+$ & 3 \\
\hline
\end{tabular}

The annual allowable cut in Canada $\left(240\right.$ million $\left.\mathrm{m}^{3}\right)$ is shrinking due to increases in protected areas while it is increasing in Sweden (97 million $\mathrm{m}^{3}$ ). Annual losses to wildfires and insects are substantial in Canada even in good years while they are negligible in Sweden (Table 3).

\section{Magnitude of Forest Activities}

Second, let us compare the forest activities of both countries.

Final felling is conducted in Canada on an area that is three times as large as in Sweden but the annual volume of wood harvested is not quite three times larger (Table 3).

Commercial thinning and selection cutting are carried out annually in Canada on less than half the area covered in Sweden where a sizeable portion (at least $25 \%$ ) of the annual harvest is the result of thinning.

Reforestation in Canada now covers annually an area that is twice as large as the area planted in Sweden, and scarification is conducted on more than $75 \%$ of the area to be reforested. Cleaning or precommercial thinning is also conducted in Canada on an annual area that is 2.5 times larger than in Sweden.

Therefore, Canada is conducting harvesting operations that are three times larger than Sweden, and carrying silvicultural treatments that are commensurate except for commercial thinning and selection cutting. Over the last 25 years, there has been a tremendous increase in silvicultural activities in Canada (Table 3).

\section{Magnitude of the Corps of Foresters and Forest Engineers}

Now we can compare the corps of foresters responsible for conducting those forest operations. The number of Canadian foresters responsible for the conduct of forest operations is 6600 , or one for every 36000 hectares of productive forest. Their importance in the forest sector is fairly large, but their reputation outside the specific field of forestry is not. By comparison, in Sweden, the number of foresters is twice that in Canada per unit area of productive forest; they number 1500 , or one for every 15000 hectares of productive forest.

One must note here that only a portion of the forestry corps is actually working in the forest (mostly those working with forest companies (18-22\%) or with woodlot owners (10-14\%)). Many foresters are researchers or teachers $(6-8 \%)$, or consultants
(8-15\%), or government officials (22-24\%), or association representatives, or corporate executives; they do not need or have time to visit the bush very often. Some do not even work in the forest sector, and some are working abroad. My information is that this picture is almost identical in Sweden and in Canada.

One can say that, over the last few decades, the importance of foresters has increased faster in Canada than in Sweden, but not necessarily that of forest engineers. With the progress made by environmental sciences, forest engineers have almost become a species in danger of extinction. Moreover, professional engineers (especially mechanical), computer specialists, geographers, biologists, wildlife managers, recreationists, landscape architects, geoscientists, and even environmentalists have started taking a fair share of the attention that was previously reserved for foresters. And the phenomenon is growing.

\section{Magnitude of the Value of Forest Products}

Nevertheless, foresters are still responsible for developing access to the forest that allows for the production of wood, which has a tremendous value at the mill door (approximately $\$ 13$ billion in Canada and $\$ 5$ billion in Sweden). This access allows also for the multiple use of the forest land by the population for which the benefits are not only economical but social, physical, intellectual, and spiritual.

After manufacturing, the value of forest products is multiplied by a factor of at least five, on which the forest industry is paying government taxes, which are in turn utilised to ensure the economic well-being of the whole population.

These fall-out benefits ( $\$ 8$ billion in 2001) are very seldom publicly attributed to the forest industry, and even less often attributed to the foresters who are responsible for growing the forests and harvesting them. This does not help raise their image or the importance of their work.

\section{Future Challenges for Forest Engineers}

This being said, we can ask: what are the future challenges for forest engineers?

\section{To Raise the Profile of Forest Engineering}

Ray Krag, Group Supervisor of Harvest Engineering at the Western Division of FERIC wrote in 2003: "There is low tolerance in Canada for poor or inadequate forest practices. The environmental importance of forests continues to increase and so does public expectation for better forest stewardship. The Canadian forest industry competes in global markets; it is under pressure to be efficient and cost competitive without causing undue damage to the environment. The challenge for the future is to convince industry, the academic community, and governments to invest more efforts and resources to raise the profile of forest engineering, and to support and promote research and university level education in that field."

\section{To Balance Operational Efficiency, Cost and Quality with Sustainable Development, Environmental Compatibility and Social Values}

Ernie Heidersdorf, Research Director at FERIC, Eastern Division, said recently: "Some of the major challenges that foresters are facing are of diverse orders because forest engineering is much more than a series of physical processes. Forest engineering provides the methodology and technology to plan forest operations, build the roads, harvest the trees, and move the fibre to 
the mill. And the processes developed and implemented via forest engineering must balance efficiency, cost and quality on one side with sustainable development, environmental compatibility, and social values on the other side. That is the overall challenge."

\section{To Redefine the Forest-based Sector}

Dean Saddler in his Newsletter of December 2002 wrote: "Scandinavians have recently broadened the definition of their forest sector and re-emphasised how forests and their multiple uses are key components of their global reputation of innovative stewards of natural resources. According to him, our challenge in Canada was also to redefine our future forest-based sector, and to determine what role we want enabling technologies and societal concerns to play in this redefinition.'

I submit that such an exercise has already started in Canada some years ago now, when the Canadian Pulp and Paper Association (CPPA) was replaced by the Forest Products Association of Canada (FPAC), and when most trade associations in the sector got the message that they either had to change or disappear. This included our Canadian forest research institutes.

Now, a National Forest Sector Innovation Council is being put together to bring the forest sector closer to federal government when priorities are determined and financial support strategies are established.

Forest Sector Clusters are being formed to bring together all regional players, including provincial governments, universities, research institutes, trade associations, woodlot owners associations, first nations representatives, and other interested parties.

To Demonstrate the Industrial Commitment to Sustainable Forest Management to Canadians and to Global Communities

Finally, a fifth National Forest Strategy (2003-2008) has just been released in Ottawa under the patronage of the Canadian Forest Strategy Coalition. This strategy does recognise "that the forest is increasingly managed for values other than timber, and opportunities exist to increase products and services from less wood and less land."

Canadian foresters can learn to do just that by carefully observing what Swedish foresters have been doing for at least the last one hundred years.

\section{Conclusion}

Daniel Guimier, Vice-President of FERIC Eastern Region, said: "The forest engineer of the past had to be first and foremost a good engineer. The forest engineer of today has to have sound engineering skills, be a people-person and be attuned to the social and environmental implications of his work. Forest is now the key word in the expression forest engineer."

Let us hope that before too long, we, foresters and forest engineers, will be able to get out of the bush, and speak out for forestry to be better recognised and understood by the general public. 